\title{
Maturational Regulation of Inositol 1,4,5-Trisphosphate Metabolism in Rabbit Airway Smooth Muscle
}

\author{
Samuel M. Rosenberg, ${ }^{\star}$ Gerard T. Berry, ${ }^{\ddagger}$ John R. Yandrasitz, ${ }^{\ddagger}$ and Michael M. Grunstein \\ Divisions of ${ }^{*}$ Pulmonary Medicine and ${ }^{\ddagger}$ Metabolism, Joseph Stokes, Jr., Research Institute, Children's Hospital of Philadelphia, \\ University of Pennsylvania School of Medicine, Philadelphia, Pennsylvania 19104
}

\begin{abstract}
Airway reactivity has been shown to vary with age; however, the mechanism(s) underlying this process remain unidentified. To elucidate the role of ontogenetic changes in phosphoinositide-linked signal transduction, we examined whether age-related differences in tracheal smooth muscle (TSM) contractility to carbachol (CCh) are associated with developmental changes in the production and metabolism of the second messenger, inositol 1,4,5-trisphosphate $\left(\right.$ Ins $\left.(1,4,5) P_{3}\right)$. In TSM segments isolated from 2 -wk-old and adult rabbits, both the maximal isometric contractile force and sensitivity (i.e., $-\log \mathrm{ED}_{\mathbf{5 0}}$ ) to $\mathrm{CCh}\left(10^{-10}-10^{-4} \mathrm{M}\right)$ were significantly greater in the immature vs. adult tissues $(P<0.001)$. Similarly, $\operatorname{Ins}(1,4,5) P_{3}$ accumulation elicited by either receptor-coupled stimulation with $\mathrm{CCh}\left(10^{-10}-10^{-4} \mathrm{M}\right)$ or post-receptor-mediated guanine nucleotide binding protein activation of permeabilized TSM with GTPrS (100 $\mu \mathrm{M})$ was also significantly enhanced in 2wk-old vs. adult TSM. Measurement of the activities of the degradative enzymes for $\operatorname{Ins}(1,4,5) P_{3}$ demonstrated that: $(a)$ mean \pm SE maximal Ins $(1,4,5) P_{3}$ 3'-kinase activity was significantly reduced in the immature vs. adult TSM (i.e., $\sim 71.7 \pm 6.0$ vs. $137.8 \pm 10.0 \mathrm{pmol} / \mathrm{min}$ per $\mathrm{mg}$ protein, respectively; $P<0.005)$; (b) by contrast, maximal $\operatorname{Ins}(1,4,5) P_{3} 5^{\prime}$ phosphatase activity was significantly increased in the immature vs. adult TSM (i.e., $27.9 \pm 1.2$ vs. $15.6 \pm 1.5 \mathrm{nmol} / \mathrm{min}$ per mg protein, respectively; $P<0.001$ ); and (c) the $K_{\mathrm{m}}$ values for Ins $(1,4,5) P_{3} 5^{\prime}$-phosphatase were 14- and 19-fold greater than those for $\operatorname{Ins}(1,4,5) \mathrm{P}_{3} 3^{\prime}$-kinase in the 2-wk-old and adult TSM, respectively. Collectively, the findings suggest that the age-related decrease in agonist-induced rabbit TSM contractility is associated with a diminution in $\operatorname{Ins}(1,4,5) P_{3}$ accumulation which is attributed, at least in part, to ontogenetic changes in the relative activities of the degradative enzymes for Ins $(1,4,5) P_{3}$. (J. Clin. Invest. 1991. 88:2032-2038.) Key words: guanine nucleotide binding protein $\cdot$ carbachol $\bullet$ signal transduction • Ins $(1,4,5) P_{3} 3^{\prime}$-kinase $-\operatorname{Ins}(1,4,5) P_{3} 5^{\prime}$-phosphatase
\end{abstract}

\section{Introduction}

There exists substantial evidence that airway smooth muscle responsiveness to various bronchoactive stimuli varies during

Address correspondence to Michael M. Grunstein, M.D., Ph.D., Division of Pulmonary Medicine, Children's Hospital of Philadelphia, 34th Street and Civic Center Boulevard, Philadelphia, PA 19104.

Received for publication 4 March 1991 and in revised form 1 August 1991.

J. Clin. Invest.

(c) The American Society for Clinical Investigation, Inc. $0021-9738 / 91 / 12 / 2032 / 07 \$ 2.00$

Volume 88, December 1991, 2032-2038 postnatal development (1-5). The mechanism(s) underlying these age-dependent changes, however, remains to be identified. Information gained from studies to date suggests that, for the most part, maturational differences in agonist-mediated airway contractility cannot be readily accounted for by concomitant changes in airway smooth muscle membrane receptor density or affinity to the agonists. Indeed, in contrast to reported maturational increases in the pulmonary receptor density to smooth muscle contractile (3) and relaxant agonists $(6,7)$, airway responsiveness to such agents has been shown to significantly decrease with aging (1-4). Thus, it appears that processes beyond cell-surface receptor binding per se likely play an important role in regulating the maturation of agonistmediated airway contractility.

Since the signal transduction mechanism (8-13) which couples most bronchoconstrictor agents to smooth muscle contraction involves phosphoinositide turnover, leading to the formation of the second messengers, 1,2-diacylglycerol and inositol 1,4,5-trisphosphate $\left(\operatorname{Ins}(1,4,5) \mathrm{P}_{3}\right){ }^{1}$ the present study examined whether maturational changes in rabbit tracheal smooth muscle (TSM) contractility to muscarinic-cholinergic stimulation are associated with ontogenetic differences in receptor-coupled and/or post-receptor-mediated production of $\operatorname{Ins}(1,4,5) \mathrm{P}_{3}$. Moreover, to the extent that the degree of Ins $(1,4,5) \mathrm{P}_{3}$ accumulation is regulated not only at the level of its production but also as the result of its subsequent dephosphorylation to $\operatorname{Ins}(1,4) \mathbf{P}_{2}$ by $\operatorname{Ins}(1,4,5) \mathrm{P}_{3}$ 5'-phosphatase and phosphorylation to $\operatorname{Ins}(1,3,4,5) \mathrm{P}_{4}$ by $\operatorname{Ins}(1,4,5) \mathrm{P}_{3} 3^{\prime}$-kinase $(8,9)$, we further investigated whether the activities of these enzymes which regulate Ins $(1,4,5) \mathrm{P}_{3}$ metabolism also vary with age. Our findings provide new evidence that: (a) TSM contractility to carbachol significantly diminishes with age; $(b)$ this maturational change in airway contractility is associated with a diminution in both muscarinic-cholinergic receptor-coupled and post-receptormediated accumulation of $\operatorname{Ins}(1,4,5) \mathrm{P}_{3}$; and $(c)$ the latter is attributed, at least in part, to age-dependent changes in the activities of $\operatorname{Ins}(1,4,5) \mathrm{P}_{3} 3^{\prime}$-kinase and Ins $(1,4,5) \mathrm{P}_{3} 5^{\prime}$-phosphatase which result in enhanced metabolism of $\operatorname{Ins}(1,4,5) \mathrm{P}_{3}$ in the maturing airway.

\section{Methods}

Contractility studies. TSM segments $\sim 1 \mathrm{~cm}$ in length were isolated from 2-wk-old and adult New Zealand white rabbits. The animals were killed by systemic air embolization after sedation and anesthesia with intramuscular injections of xylazine $(10 \mathrm{mg} / \mathrm{kg})$ and ketamine hydrochloride $(30 \mathrm{mg} / \mathrm{kg})$, respectively. The TSM segments were cleaned of loose connective tissue, placed in siliconized $20-\mathrm{ml}$ organ baths (Harvard Apparatus Co., Inc., S. Natick, MA), and suspended longitudi-

1. Abbreviations used in this paper: $\mathrm{CaM}$, calmodulin; $\mathrm{CCh}$, carbachol; G-protein, guanine nucleotide binding protein; Ins $(1,4) \mathrm{P}_{2}$, inositol 1,4biphosphate; Ins $(1,4,5) \mathrm{P}_{3}$, inositol 1,4,5-trisphosphate; $\operatorname{Ins}(1,3,4,5) \mathrm{P}_{4}$, inositol 1,3,4,5-tetrakiphosphate; TSM, tracheal smooth muscle. 
nally by firm stainless steel wire triangular supports. The lower support was attached to the base of the organ bath and the upper support was connected via a gold chain to an isometric force transducer (FTO3; Grass Instrument Co., Quincy, MA) from which isometric force was continuously monitored on a multichannel recorder (Sensor Medics, Yorba Linda, CA). Each force transducer was mounted on a rack and pinion clamp which was used to adjust the resting length of the airway segment. Care was taken to place the membranous portion of the TSM segment between the supports to maximize the tension generated by the contracting trachealis muscle. The tissues were bathed in modified Krebs-Ringer solution of composition (in $\mathrm{mM}$ ): $125 \mathrm{NaCl}, 15$ $\mathrm{NaHCO}_{3}, 5 \mathrm{KCl}, 2.5 \quad \mathrm{CaCl}_{2}: 2 \mathrm{H}_{2} \mathrm{O}, 1.46 \quad \mathrm{MgSO}_{4}: 7 \mathrm{H}_{2} \mathrm{O}, 1.2$ $\mathrm{NaH}_{2} \mathrm{PO}_{4}: \mathrm{H}_{2} \mathrm{O}$, and 22 dextrose. The baths were aerated with $95 \% \mathrm{O}_{2}$ and $5 \% \mathrm{CO}_{2}$, a pH of $7.4 \pm 0.02$ was maintained, and the temperature was kept at $37^{\circ} \mathrm{C}$.

The airway segments were equilibrated in organ baths for at least 1 $h$, during which time they were passively stretched on several occasions to a tension of 6-8 $\mathrm{g}$, and the baths were then rinsed with fresh buffer solution. The resting tensions of the immature and adult tissues were then set at between $0.5-1$ and $1.5-2 \mathrm{~g}$, respectively, which represented the passive tensions required to establish their optimal length for contraction (14). To examine the maturational effects of muscarinic-cholinergic receptor stimulation on TSM contractility, carbachol, an agonist resistant to hydrolysis by endogenous cholinesterases, was administered to the tissues under resting baseline tension in a cumulative dose-response fashion in final organ bath concentrations ranging from $10^{-10}$ to $10^{-4} \mathrm{M}$.

Measurement of Ins $(1,4,5) P_{3}$ accumulation. Carbachol-induced mass changes in Ins $(1,4,5) \mathrm{P}_{3}$ were assayed in TSM sections isolated from the cervical trachealis muscle of 2-wk-old and adult rabbits. The smooth muscle slices (1-8 mg wet $\mathrm{wt}$ ) were cleaned of loose connective tissue and cartilage, and preincubated for $60 \mathrm{~min}$ in multiwell tissue culture plates, each containing $2 \mathrm{ml}$ of oxygenated $\left(95 \% \mathrm{O}_{2} / 5 \% \mathrm{CO}_{2}\right)$ buffer (as above) at $37^{\circ} \mathrm{C}$ and $\mathrm{pH}$ of 7.4. In studies designed to determine the time course of Ins $(1,4,5) \mathrm{P}_{3}$ accumulation, TSM sections were exposed to carbachol for time periods ranging from 1 to $30 \mathrm{~s}$. Based on the findings from the latter studies (see Results), in separate experiments, the peak dose-dependent changes in $\operatorname{Ins}(1,4,5) \mathrm{P}_{3}$ in response to carbachol $\left(10^{-10}-10^{-4} \mathrm{M}\right)$ were determined at $5 \mathrm{~s}$ after each administered dose of the agonist. Accumulation of $\operatorname{Ins}(1,4,5) \mathrm{P}_{3}$ was also determined in response to post-receptor-mediated activation of guanine nucleotide binding proteins (G-proteins) using the nonhydrolyzable GTP analogue, GTP $\gamma$ S. In these studies, TSM sections were prepared as above and, after a 60 -min incubation in the above buffer, the tissues were exposed to saponin $\left(100 \mu \mathrm{g} / \mathrm{ml}, 25^{\circ} \mathrm{C}, 20 \mathrm{~min}\right)$ in a permeabilization solution of composition (15): $120 \mathrm{mM} \mathrm{KCl}, 4 \mathrm{mM} \mathrm{MgCl}_{2}: 6 \mathrm{H}_{2} \mathrm{O}$, $15 \mathrm{mM}$ Hepes, pH 7.1, $25 \mathrm{mM} \mathrm{NaCl}, 1 \mathrm{mM} \mathrm{NaH} \mathrm{PO}_{4}: \mathrm{H}_{2} \mathrm{O}, 2.5 \mathrm{mM}$ ATPNa $2,150 \mu \mathrm{M}$ EGTA, $20 \mu \mathrm{M} \mathrm{CaCl}_{2}: 2 \mathrm{H}_{2} \mathrm{O}, 1 \mathrm{mM}$ myo-inositol. The tissues were then rinsed with the permeabilization solution, and placed in fresh media containing GTP $\gamma \mathrm{S}(100 \mu \mathrm{M})$ for $20 \mathrm{~min}$.

The above reactions were terminated with $300 \mu \mathrm{l}$ of ice-cold $1 \mathrm{~N}$ perchloric acid. After homogenization for $30 \mathrm{~s}$, the samples were centrifuged $\left(20,000 \mathrm{~g} ; 4^{\circ} \mathrm{C}, 20 \mathrm{~min}\right)$ and $250 \mu \mathrm{l}$ of supernatant was removed from each sample and added to $50 \mu \mathrm{g}$ of $5 \mathrm{~N} \mathrm{~K}_{2} \mathrm{CO}_{3}$. The samples were kept on ice for $20 \mathrm{~min}$ and $100-\mu \mathrm{l}$ aliquots of supernatant were removed for $\operatorname{Ins}(1,4,5) \mathrm{P}_{3}$ determination. The Ins $(1,4,5) \mathrm{P}_{3}$ level was measured for each sample using a competitive binding assay which uses a bovine-derived adrenal binding protein specific for $\operatorname{Ins}(1,4,5) \mathrm{P}_{3}$ (Amersham Corp., Arlington Heights, IL). The assay has a sensitivity of $<0.2$ pmol. Tissue protein concentrations were determined according to the method of Lowry et al. (16) using BSA as a standard, and the measured Ins $(1,4,5) \mathrm{P}_{3}$ levels were normalized to $\mathrm{mg}$ protein of the tissue samples. The mean $( \pm \mathrm{SE})$ protein content of TSM samples from 2-wk-old and adult tissues amounted to $0.051( \pm 0.017)$ and $0.062( \pm 0.013) \mathrm{mg}$ protein/mg TSM, respectively.

Assays of Ins $(1,4,5) P_{3} 3^{\prime}$-kinase and Ins $(1,4,5) P_{3} 5^{\prime}$-phosphatase activities. The TSM homogenate preparation and enzyme analyses were performed as previously described in rat brain tissue (17). Trachealis muscle was rapidly removed from 2-wk-old and adult rabbits, rinsed with $0.15 \mathrm{M} \mathrm{NaCl}$, and frozen in liquid nitrogen. Homogenization buffer of composition $50 \mathrm{mM}$ Tris/ $\mathrm{HCl}, \mathrm{pH} 7.5,250 \mathrm{mM}$ sucrose, 3 $\mathrm{mM} \mathrm{MgCl} 2,1.5 \mathrm{mM}$ EGTA, $1 \mathrm{mM}$ DTT, $2 \mu \mathrm{g} / \mathrm{ml}$ leupeptin, $2 \mu \mathrm{g} / \mathrm{ml}$ aprotinin, and $0.5 \mathrm{mM}$ PMSF was added to the frozen TSM at $5 \mu \mathrm{l} / \mathrm{mg}$ tissue. The sample was homogenized and centrifuged $\left(1,000 \mathrm{~g}, 4^{\circ} \mathrm{C}, 15\right.$ $\mathrm{min}$ ) and the supernatant was then used as crude preparation for the enzyme assays.

Ins $(1,4,5) \mathrm{P}_{3}$ 3'-kinase activity was assayed by determining the production of inositol 1,3,4,5-tetrakisphosphate $\left(\operatorname{Ins}(1,3,4,5) \mathrm{P}_{4}\right)$ from Ins $(1,4,5) \mathrm{P}_{3}$. The incubation buffer had the following composition: 50 $\mathrm{mM}$ Tris/HCl, pH 7.5, $100 \mathrm{mM} \mathrm{KCl}, 10 \mathrm{mM} \mathrm{ATPNa}, 20 \mathrm{mM}$ $\mathrm{MgCl}_{2}: 6 \mathrm{H}_{2} \mathrm{O}, 1 \mathrm{mM}$ DTT, $5 \mathrm{mM}$ 2,3-diphosphoglycerate, $2 \mathrm{mM}$ EGTA, $100,000-200,000 \mathrm{cpm} / \mathrm{ml}\left[{ }^{3} \mathrm{H}\right] \mathrm{Ins}(1,4,5) \mathrm{P}_{3}$. The free $\mathrm{Ca}^{2+}$ concentration of the incubation buffer was determined at $<10^{-9} \mathrm{M}$. Ins $(1,4,5) \mathrm{P}_{3}$ was then added to the buffer to yield concentrations varying between 0.5 and $50 \mu \mathrm{M}$. The $\left[{ }^{3} \mathrm{H}\right] \operatorname{Ins}(1,4,5) \mathrm{P}_{3}$-containing incubation buffer $(0.2 \mathrm{ml})$ was added to the enzyme preparation $(5-20 \mu \mathrm{l})$, followed by incubation in a shaking bath for $5 \mathrm{~min}$ at $37^{\circ} \mathrm{C}$. The reaction was terminated by adding $50 \mu \mathrm{l}$ of $1 \mathrm{~N} \mathrm{H}_{3} \mathrm{PO}_{4}$ followed by $50 \mu \mathrm{l} 1 \mathrm{~N}$ $\mathrm{NaOH}$. The inositol phosphates were separated on a $0.7-\mathrm{ml}$ formate form column (Dowex/AG 1-X8; Bio-Rad Laboratories, Richmond, CA). Each column was washed with $20 \mathrm{ml}$ of $0.75 \mathrm{M}$ ammonium formate in $0.1 \mathrm{M}$ formic acid to remove unreacted $\operatorname{Ins}(1,4,5) \mathrm{P}_{3}$. Each column was then washed with $12 \mathrm{ml}$ of $1.5 \mathrm{M}$ ammonium formate in $0.1 \mathrm{M}$ formic acid for elution of $\operatorname{Ins}(1,3,4,5) \mathrm{P}_{4}$. The identity of the product, Ins $(1,3,4,5) \mathrm{P}_{4}$, was confirmed by demonstrating identical elution properties using authentic $\left[{ }^{3} \mathrm{H}\right] \mathrm{Ins}(1,3,4,5) \mathrm{P}_{4}$. In separate experiments, to independently determine the effects of supplemental $\mathrm{Ca}^{2+}$ and $\mathrm{Ca}^{2+}$ /calmodulin (CaM) on $3^{\prime}$-kinase activity, the homogenization and reaction buffers were treated with $\mathrm{CaCl}_{2}: 2 \mathrm{H}_{2} \mathrm{O}$ in the absence and presence of added $\mathrm{CaM}(20 \mu \mathrm{g} / \mathrm{ml})$ to achieve a calculated free $\mathrm{Ca}^{2+}$ concentration of $10^{-6} \mathrm{M}$, on the assumption that the apparent affinity constant of EGTA for $\mathrm{Ca}^{2+}$ is $5.02 \times 10^{7} \mathrm{M}^{-1}$ at $\mathrm{pH}$ 7.5.

Ins $(1,4,5) \mathrm{P}_{3} 5^{\prime}$-phosphatase activity was assayed by determining the production of inositol 1,4-bisphosphate $\left(\operatorname{Ins}(1,4) \mathrm{P}_{2}\right)$ from $\operatorname{Ins}(1,4,5) \mathrm{P}_{3}$. The incubation buffer had the following composition: $50 \mathrm{mM}$ Hepes/ $\mathrm{KOH}, \mathrm{pH} 7.0,1 \mathrm{mM} \mathrm{MgCl}$, $1 \mathrm{mM}$ DTT, 100,000-200,000 cpm/ml $\left[{ }^{3} \mathrm{H}\right] \operatorname{Ins}(1,4,5) \mathrm{P}_{3}$, and contained varying concentrations of $\operatorname{Ins}(1,4,5) \mathrm{P}_{3}$ $(2.5-500 \mu \mathrm{M})$. The incubation buffer $(0.2 \mathrm{ml})$ was added to the enzyme preparation $(5-20 \mu \mathrm{l})$ and incubated in a shaking bath for $5 \mathrm{~min}$ at $37^{\circ} \mathrm{C}$. Termination of the reaction and separation of inositol phosphates were performed as above, except that Ins $(1,4) \mathrm{P}_{2}$ was eluted with $20 \mathrm{ml}$ of $0.5 \mathrm{M}$ ammonium formate in $0.1 \mathrm{M}$ formic acid. The identity of the product, Ins $(1,4) \mathrm{P}_{2}$, was confirmed by demonstrating identical elution properties with authentic $\left[{ }^{3} \mathrm{H}\right] \operatorname{Ins}(1,4) \mathrm{P}_{2}$. Using this method, it has been previously confirmed that $>95 \%$ of the product is $\operatorname{Ins}(1,4) \mathrm{P}_{2}$ when analyzed on an HPLC column (Partisil/SAX 10; Waters Associates, Milford, MA) (17). In separate experiments, the activity of 5 'phosphatase was determined in the complete TSM homogenate, as well as in the supernatant of the preparation, to assess whether significant 5 '-phosphatase activity was lost during centrifugation.

In preliminary studies, we determined that the reaction rates for both the 3 '-kinase and $5^{\prime}$-phosphatase assays were linear for at least up to $20 \mathrm{~min}$, and were also linear with $10-120 \mathrm{mg}$ added protein. The enzyme activities were calculated as follows: cpm of $\operatorname{Ins}(1,3,4,5) \mathrm{P}_{4}$ or Ins $(1,4) \mathrm{P}_{2} /$ specific activity of $\left[{ }^{3} \mathrm{H}\right] \operatorname{Ins}(1,4,5) \mathrm{P}_{3} \times$ incubation time $(5$ $\min )$. The maximal specific activities $\left(V_{\max }\right)$ and apparent $K_{\mathrm{m}}$ values were determined by standard Michaelis-Menton analysis of the data.

Data analyses. At the end of each contractility experiment, the TSM segments were blotted on a gauze pad and weighed. The contractile forces were normalized to tissue weight, and expressed as grams of active force per grams tissue weight. In characterizing the dose-response relationships, the maximal contractile responses $\left(T_{\max }\right)$ were determined, as well as the negative logarithm of the agonist concentration producing $50 \%$ of the $T_{\max }$ response $\left(-\operatorname{logED} D_{50}\right)$. The latter and the enzyme kinetics data were expressed as means \pm standard error of the means. Statistical analyses were performed using two-tailed $t$ tests and 
analysis of variance with multiple comparisons of means where appropriate. A $P$ value of 0.05 or less was considered significant.

Materials. The drugs and other reagents used included xylazine (Haver:Moba Corp., Shawnee, KS), ketamine hydrochloride (Quad Pharmaceuticals, Indianapolis, IN). $\left[{ }^{3} \mathrm{H}\right]$ inositol-1,4,5-trisphosphate, and the inositol-1,4,5-trisphosphate, $\left[{ }^{3} \mathrm{H}\right]$ inositol-1,4-bisphosphate, $\left[{ }^{3} \mathrm{H}\right]$ inositol-1,3,4,5-tetrakisphosphate, inositol-1,4,5-trisphosphate assay system were purchased from Amersham Corp. Carbachol, 5'-0-[3thiotriphosphate] (GTP $\gamma S$ ), DTT, saponin, aprotinin, leupeptin, PMSF, 2,3-diphosphoglycerate, ATPNa 2 , ammonium formate, myoinositol, and calmodulin were purchased from Sigma Chemical Co., St. Louis, MO. Anion exchange columns and resin were obtained from Bio-Rad Laboratories.

\section{Results}

Maturational effects of carbachol on TSM contractility. In both immature and adult TSM segments, administration of carbachol $(\mathrm{CCh})$ produced dose-dependent increases in their isometric force of contraction. Fig. 1 compares the average $($ mean \pm SE) contractile dose-response curves obtained in the 2 -wk and adult TSM segments. The mean maximal contractile $\left(T_{\max }\right)$ response to $\mathrm{CCh}$ was significantly greater in the immature vs. adult tissues, amounting to $215.2( \pm 19.6)$ vs. 137.5 $( \pm 7.9) \mathrm{g} / \mathrm{g}$ TSM wt, respectively $(P<0.005)$. When normalized to their individual $T_{\max }$ responses, the contractile dose-response curves to $C C h$ provided mean $\mathrm{PD}_{2}$ (i.e., $-\operatorname{logED} \mathrm{D}_{50}$ ) values of $6.74( \pm 0.08)$ and $6.19( \pm 0.01)$ in the 2-wk-old and adult TSM, respectively $(P<0.001)$, indicating that TSM sensitivity to the cholinergic agonist was significantly lower in the adult tissues.

Maturational differences in Ins $(1,4,5) P_{3}$ accumulation. We examined whether the above finding is associated with an agedependent difference in $\mathrm{CCh}$-induced production of the second messenger, Ins $(1,4,5) \mathrm{P}_{3}$. CCh elicited time and dose-dependent increases in $\operatorname{Ins}(1,4,5) \mathrm{P}_{3}$ concentration. As shown in Fig. 2 , in both immature and adult TSM, CCh $(100 \mu \mathrm{M})$ produced a qualitatively similar transient $\operatorname{Ins}(1,4,5) \mathrm{P}_{3}$ response, characterized by an initial rapid rise in $\operatorname{Ins}(1,4,5) \mathrm{P}_{3}$ which peaked at $\sim 5 \mathrm{~s}$ and returned to baseline values by $\sim 10 \mathrm{~s}$. This transient Ins $(1,4,5) \mathrm{P}_{3}$ response is similar to that previously reported with CCh in adult bovine TSM (18). The dose-depen-

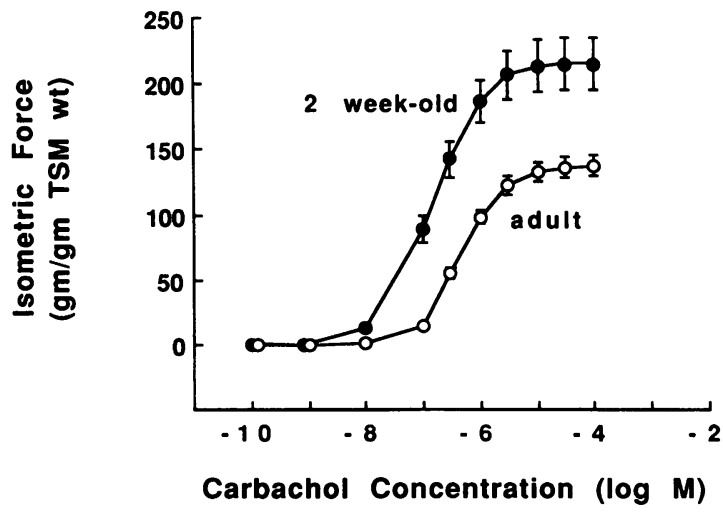

Figure 1. Comparison of isometric contractile dose-response relationships to CCh in TSM segments from 2-wk-old $(n=12)$ and adult $(n=14)$ rabbits. Data are mean \pm SE values.

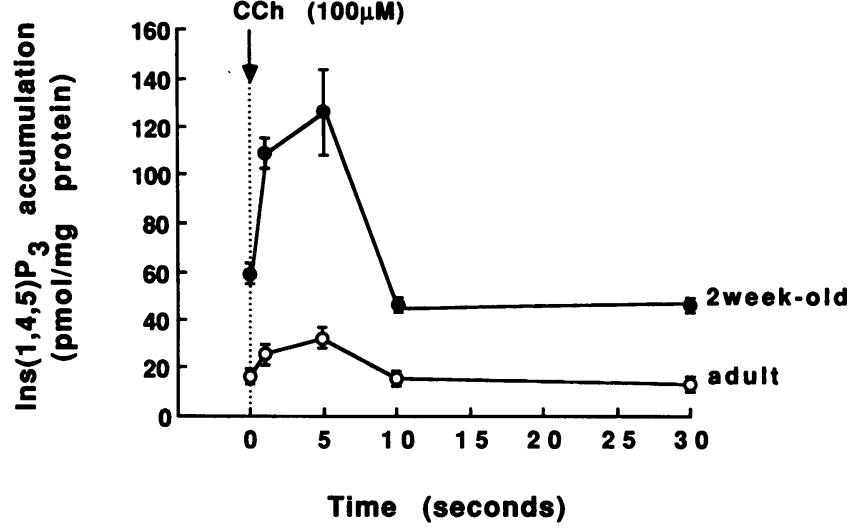

Figure 2. Time course of $\operatorname{Ins}(1,4,5) \mathrm{P}_{3}$ accumulation in response to $100 \mu \mathrm{M} \mathrm{CCh}$ in 2-wk-old and adult TSM. Measurements of Ins $(1,4,5) \mathrm{P}_{3}$ were obtained at various times indicated after $\mathrm{CCh}$ administration. Data are mean \pm SE values from three separate experiments conducted at each age, with duplicate determinations obtained at each time point.

dent effects of $\mathrm{CCh}$ on peak Ins $(1,4,5) \mathrm{P}_{3}$ accumulation, determined at $5 \mathrm{~s}$ after each administered dose of the agonist, are shown in Fig. 3. Both the basal levels and $\mathrm{CCh}$-induced increases in Ins $(1,4,5) \mathrm{P}_{3}$ were significantly greater in the immature tissues. The basal mean $( \pm \mathrm{SE})$ levels of $\operatorname{Ins}(1,4,5) \mathrm{P}_{3}$ amounted to $66.0( \pm 6.7)$ and $18.4( \pm 2.9) \mathrm{pmol} / \mathrm{mg}$ protein in the immature and adult tissues, respectively $(P<0.001)$; and the corresponding mean maximal $\mathrm{CCh}$-induced levels of Ins $(1,4,5) \mathrm{P}_{3}$ were $211( \pm 57.9)$ and $40.5( \pm 8.3) \mathrm{pmol} / \mathrm{mg}$ protein, respectively $(P<0.001)$.

In extended studies, we examined whether the above agedependent differences in receptor-coupled Ins $(1,4,5) \mathrm{P}_{3}$ accumulation also occurred during post-receptor-mediated stimulation of Ins $(1,4,5) P_{3}$ by activation of $G$-proteins in saponin-permeabilized TSM with the nonhydrolyzable GTP analogue,

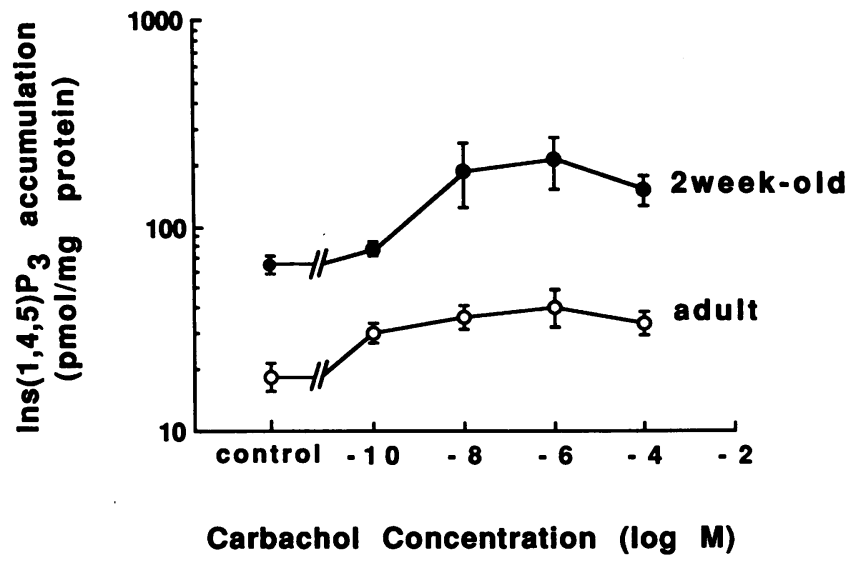

Figure 3. Comparison of dose-dependent effects of $\mathrm{CCh}$ on Ins $(1,4,5) \mathrm{P}_{3}$ accumulation in 2-wk-old and adult TSM. Data represent mean \pm SE values for seven experiments conducted at each age, with measurements obtained at $5 \mathrm{~s}$ after each administered concentration of CCh. Note: Data are plotted on a logarithmic scale to accommodate the large differences between the 2-wk-old and adult tissues. 


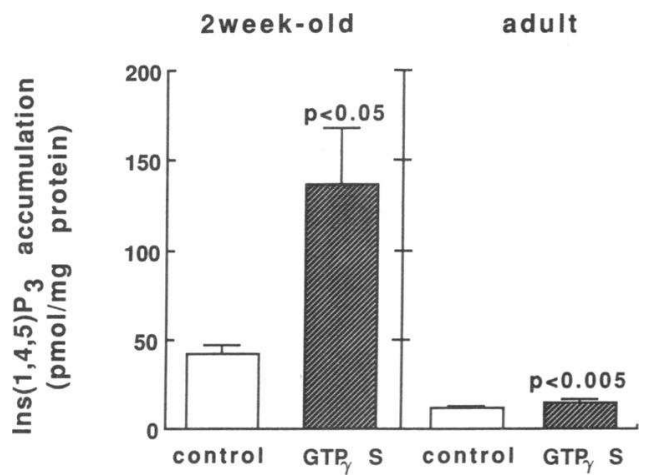

Figure 4. Comparison of maximal levels of $\operatorname{Ins}(1,4,5) \mathrm{P}_{3}$ obtained in 2-wk-old $(n=4)$ and adult $(n=5)$ saponin-permeabilized control (i.e., untreated) tissues and TSM treated with GTP $\gamma \mathrm{S}(100 \mu \mathrm{M}$ for 20 $\mathrm{min})$. Data are mean $\pm \mathrm{SE}$ values.

$\mathrm{GTP}_{\gamma} \mathrm{S}$. The latter has been shown to stimulate $\operatorname{Ins}(1,4,5) \mathrm{P}_{3}$ accumulation and potentiate contraction of permeabilized smooth muscle cells $(15,19-21)$. As shown in Fig. 4, control (i.e., basal) values of $\operatorname{Ins}(1,4,5) \mathrm{P}_{3}$ were significantly higher in the 2-wk-old vs. adult permeabilized TSM, amounting to 42.4 $( \pm 4.6)$ vs. $12.0( \pm 0.9) \mathrm{pmol} / \mathrm{mg}$ protein, respectively $(P$ $<0.001)$. Upon maximal stimulation with GTP $\gamma \mathrm{S}(100 \mu \mathrm{M}$ for $20 \mathrm{~min}$ ), there occurred significant increased accumulation of Ins $(1,4,5) \mathrm{P}_{3}$ in both the 2-wk-old and adult TSM. The increases in Ins $(1,4,5) \mathrm{P}_{3}$, however, were markedly greater in the immature tissues, and averaged $136.2( \pm 31.4)$ vs. $15.1( \pm 1.1) \mathrm{pmol} /$ $\mathrm{mg}$ protein in the 2 -wk-old vs. adult TSM, respectively $(P$ $<0.001$ ). It should be noted that in separate experiments conducted in the absence of saponin treatment there was no significant rise in Ins $(1,4,5) \mathrm{P}_{3}$ levels in response to GTP $\gamma \mathrm{S}$ in either

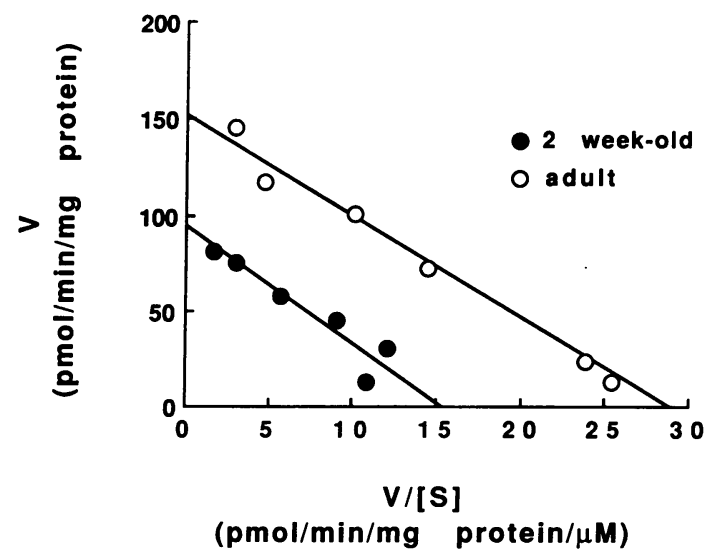

Figure 5. Representative Hofstee plots of Ins $(1,4,5) \mathrm{P}_{3} 3^{\prime}$-kinase activity obtained in sections from 2-wk-old and adult rabbit TSM. The data relate measured Ins $(1,4,5) \mathrm{P}_{3} 3^{\prime}$-kinase activity (ordinate) to the enzyme activity divided by the corresponding substrate concentration (abscissa). Maximal specific activity $\left(V_{\max }\right)$ represented by the $y$ intercept value is lower in the 2-wk-old vs. adult TSM, amounting to 92.3 vs. $153.2 \mathrm{pmol} / \mathrm{min}$ per $\mathrm{mg}$ protein, respectively. The corresponding Michaelis-Menton constant, $K_{\mathrm{m}}$, represented by the negative slope of each relationship is similar for both ages, amounting to 6.1 and $5.5 \mu \mathrm{M}$ in the 2-wk-old and adult TSM, respectively.
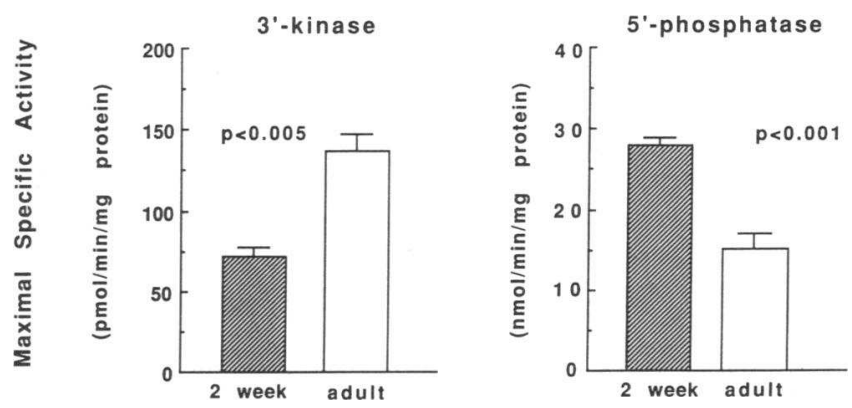

Figure 6. Comparison of $V_{\max }$ values for $\operatorname{Ins}(1,4,5) \mathrm{P}_{3}$ 3'-kinase (left) and $\operatorname{Ins}(1,4,5) \mathrm{P}_{3} 5^{\prime}$-phosphatase (right) activity in 2-wk-old $(n=15)$ and adult $(n=10)$ TSM preparations. Data are mean \pm SE values.

the immature or adult TSM (data not shown), indicating that permeabilization of the tissues was required for effective stimulation of $\operatorname{Ins}(1,4,5) \mathrm{P}_{3}$ production by the GTP analogue.

Maturation of Ins $(1,4,5) P_{3} 3^{\prime}$-kinase and $\operatorname{Ins}(1,4,5) P_{3} 5^{\prime}$ phosphatase enzyme activities. In view of the above differences in both agonist-coupled and post-receptor-mediated Ins $(1,4,5) \mathrm{P}_{3}$ accumulation in maturing TSM, we next examined whether the latter were associated with maturational changes in the apparent activities of the degradative enzymes for Ins $(1,4,5) P_{3}$. The enzyme activity $(V)$ vs. substrate concentration ([S]) relationships for both $\operatorname{Ins}(1,4,5) \mathrm{P}_{3} 3^{\prime}$-kinase and Ins $(1,4,5) \mathrm{P}_{3}$ 5'-phosphatase demonstrated classical saturation kinetics within the range of administered substrate concentrations. As exemplified by the Hofstee plot relating $\mathrm{V}$ to $\mathrm{V} /[\mathrm{S}]$ for 3 '-kinase activity in representative preparations from 2-wk-old and adult TSM in Fig. 5, maximal specific activity $\left(V_{\max }\right)$ was reduced in the immature tissues. The mean $( \pm \mathrm{SE}) V_{\max }$ values for $3^{\prime}$-kinase in the 2-wk-old and adult TSM amounted to 71.7 $( \pm 6.0)$ and $137.8( \pm 10.0) \mathrm{pmol} / \mathrm{min}$ per $\mathrm{mg}$ protein, respectively $(P<0.005)$ (Fig. 6, left). The corresponding apparent $K_{\mathrm{m}}$ values for the 2 -wk-old and adult tissues, however, were similar and averaged 5.1 and $5.0 \mu \mathrm{M}$, respectively.

Relative to 3'-kinase activity, the mean $V_{\max }$ values for 5'phosphatase were significantly greater in both the immature and adult TSM (Fig. 6, right), amounting to $27.9( \pm 1.2)$ and $15.6( \pm 1.5) \mathrm{nmol} / \mathrm{min}$ per $\mathrm{mg}$ protein, respectively. These values are significantly different $(P<0.001)$, indicating that maximal 5'-phosphatase activity was relatively enhanced in the immature vs. adult TSM. In contrast, the mean apparent $K_{\mathrm{m}}$ values for $5^{\prime}$-phosphatase in the 2-wk-old and adult tissues were similar at 70.6 and $95.3 \mu \mathrm{M}$, respectively; and the latter values represent 14- and 19-fold increases above the corresponding $K_{\mathrm{m}}$ determinations for 3 '-kinase. It should be noted that whereas the above determinations of 5 -phosphatase activity pertain to measurements made in supernatant preparations, the $V_{\max }$ values for the enzyme averaged only $15.9 \%$ greater in complete TSM homogenate preparations, indicating that most of the 5'-phosphatase activity was contained in the supernatant fraction.

Effects of $\mathrm{Ca}^{2+}$ and $\mathrm{Ca}^{2+} /$ calmodulin on Ins $(1,4,5) \mathrm{P}_{3} 3^{\prime}-k i$ nase activity. Earlier studies have reported that $\operatorname{Ins}(1,4,5) \mathrm{P}_{3}$ $3^{\prime}$-kinase activity is stimulated by physiological concentrations of free $\mathrm{Ca}^{2+}$ in the presence of calmodulin (22-25). To evaluate whether this effect of $\mathrm{Ca}^{2+}$ varies maturationally, maximal 3'-kinase activity was determined in 2-wk-old and adult TSM prepa- 
rations incubated in $\mathrm{Ca}^{2+}$-deficient buffer (i.e., $<10^{-9} \mathrm{M}$ calculated free $\left.\mathrm{Ca}^{2+}\right)$ and buffer containing a final concentration of $10^{-6}$ free $\mathrm{Ca}^{2+}$, both in the absence and presence of added calmodulin (CaM). In both the immature and adult TSM preparations, relative to control tissues, maximal 3'-kinase activity was significantly enhanced in the corresponding tissues incubated with supplemental $\mathrm{Ca}^{2+}$, both with and without added $\mathrm{CaM}$ (Fig. 7). The mean ( $\pm \mathrm{SE}) V_{\max }$ values for $3^{\prime}$-kinase in the presence of added $\mathrm{Ca}^{2+}$ (Fig. 7; hatched bars) amounted to 156.9 $( \pm 9.4)$ and $230.6( \pm 22.9) \mathrm{pmol} / \mathrm{min}$ per $\mathrm{mg}$ protein in the 2wk-old and adult tissues, respectively, both of which signifcantly exceeded $(P<0.005)$ the corresponding values of 71.5 $( \pm 5.2)$ and $142( \pm 1.8) \mathrm{pmol} / \mathrm{min}$ per $\mathrm{mg}$ protein obtained in the respective control (i.e., $\mathrm{Ca}^{2+}$ deficient) TSM preparations. Moreover, it should be noted that, as for the control tissues, the enhanced mean $V_{\max }$ values for the $\mathrm{Ca}^{2+}$-stimulated adult TSM significantly exceeded the corresponding values obtained in the $\mathrm{Ca}^{2+}$-stimulated 2-wk-old tissues $(P<0.05)$. Of interest, there was no further increase in 3 -kinase activity with the addition of $\mathrm{CaM}$ in either the immature or adult tissues (Fig. 7, filled bars). To the extent that the 3 -kinase activity was assayed in crude tissue preparations, the lack of further increase in enzyme activity with the addition of exogenous $\mathrm{CaM}$ suggests that the tissues likely contained a significant endogenous amount of $\mathrm{CaM}$ which allowed for optimal enzyme activity.

\section{Discussion}

Recent studies have demonstrated that airway smooth muscle isolated from different species undergoes an age-dependent diminution in its contractile responsiveness to muscarinic-cholinergic agonists and other constrictor agents (1-4). In addition, there is emerging information that the in vivo bronchoconstrictor response to inhalation of a cholinergic agonist also diminishes with age in maturing human infants (5). The findings of the present study agree with these earlier reports, and provide new evidence that the increased sensitivity to cholinergic stimulation in the maturing rabbit airway smooth muscle is associated with a relatively enhanced basal and carbachol-induced accumulation of the second messenger, $\operatorname{Ins}(1,4,5) \mathrm{P}_{3}$, which mediates the mobilization of intracellular $\mathrm{Ca}^{2+}$ to initiate smooth muscle contraction.

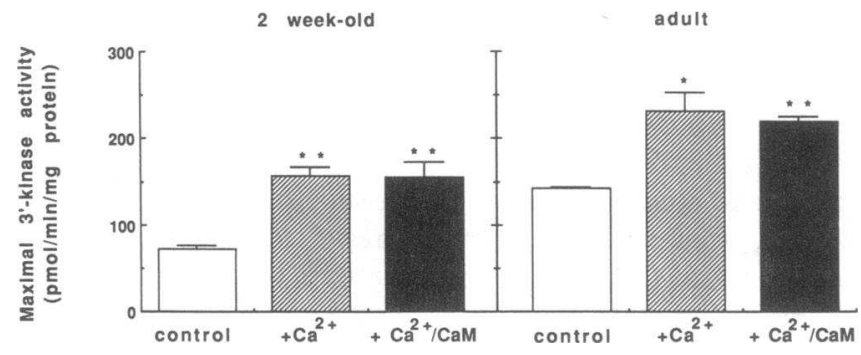

Figure 7. Comparison of $V_{\max }$ values for Ins $(1,4,5) \mathrm{P}_{3} 3^{\prime}$-kinase activity obtained in 2-wk-old (left) and adult (right) TSM preparations placed in control (i.e., $\mathrm{Ca}^{2+}$ deleted) buffer (open bars) and buffer containing $10^{-6} \mathrm{M}$ free $\mathrm{Ca}^{2+}$ concentration without (hatched bars) and with (filled bars) supplemental calmodulin $(20 \mu \mathrm{g} / \mathrm{ml})$. Data are mean $\pm \mathrm{SE}$ values. ${ }^{*} P<0.05 ;{ }^{* *} P<0.005$ for comparisons relative to control values.
The observed transient rise in Ins $(1,4,5) \mathrm{P}_{3}$ with CCh (Fig. 2) was similar to that recently reported using the same agonist in adult bovine TSM (18). Moreover, both the measured basal and $C C h$-induced increases in $\operatorname{Ins}(1,4,5) \mathrm{P}_{3}$ obtained in the adult rabbit tissues were comparable in magnitude to those reported in adult bovine TSM (18). On the other hand, in contrast to the transient nature of the $\operatorname{Ins}(1,4,5) \mathrm{P}_{3}$ response to $C C h$, we recently found that stimulation of rabbit TSM with the constrictor peptide, endothelin-1, elicits a more gradual initial rise in Ins $(1,4,5) \mathrm{P}_{3}$ which is followed by a sustained elevation lasting at least $10 \mathrm{~min}(14)$. Notwithstanding these agonist-specific differences in the time course of the Ins $(1,4,5) \mathrm{P}_{3}$ response, the present findings demonstrate an age-dependent difference in the magnitude of CCh-induced Ins $(1,4,5) \mathrm{P}_{3}$ accumulation (Fig. 3) which closely parallels the pattern of maturational change in the dose-dependent effects of endothelin-1 on Ins $(1,4,5) \mathrm{P}_{3}$ accumulation in maturing rabbit TSM (14). Taken together, these observations suggest that, at least in rabbit TSM, the ontogenetic mechanism(s) regulating the magnitude of the Ins $(1,4,5) \mathrm{P}_{3}$ response to agonist stimulation is not determined by receptor specificity per se. Moreover, when comparing the present findings to those from other developmental studies using different tissue preparations, a qualitatively similar pattern of maturational diminution in $\mathrm{CCh}$-induced inositol phosphate accumulation is seen in cortical brain tissue from maturing rats (26).

As in the maturing rat cerebral cortex (26), the density of muscarinic-cholinergic receptors in bovine tracheal smooth muscle has been found to increase with age, while receptor affinity remains relatively constant (3). These findings, together with the above observations, raise the consideration that immature tissues may have a more efficient transduction mechanism coupling agonist-receptor interaction to stimulation of membrane phosphatidylinositol hydrolysis. While the latter possibility remains to be investigated, the present finding that age-dependent differences in $\operatorname{Ins}(1,4,5) \mathrm{P}_{3}$ accumulation were also obtained during selective post-receptor-mediated G-protein activation with GTP $\gamma \mathrm{S}$ (Fig. 4) suggests that the magnitude of the $\operatorname{Ins}(1,4,5) \mathrm{P}_{3}$ response is developmentally regulated, at least in part, at a site(s) distal to receptor/G-protein interaction. Indeed, in further support of this concept, the present observations demonstrate that the activity of the enzymes which metabolize Ins $(1,4,5) \mathrm{P}_{3}$ vary significantly in the maturing airway smooth muscle. In this regard, the observation that the $V_{\max }$ for $\operatorname{Ins}(1,4,5) \mathrm{P}_{3} 3^{\prime}$-kinase in 2-wk-old TSM is $~ 50 \%$ of that obtained in adult tissues (Fig. 6, left) suggests that the relatively enhanced agonist-induced rise in $\operatorname{Ins}(1,4,5) \mathrm{P}_{3}$ levels in the 2-wk-old TSM reflects an immaturity of the phosphorylation pathway for Ins $(1,4,5) \mathbf{P}_{3}$ metabolism. By contrast, the increased $V_{\max }$ for $\operatorname{Ins}(1,4,5) \mathrm{P}_{3} 5^{\prime}$-phosphatase activity obtained in the 2-wk-old vs. adult TSM (Fig. 6, right) suggests an age-dependent diminution in the relative contribution of the dephosphorylation route for $\operatorname{Ins}(1,4,5) \mathrm{P}_{3}$ metabolism.

The observed developmental change in $3^{\prime}$-kinase activity is similar to that reported in the maturing rat cerebral cortex, wherein 3'-kinase activity at two weeks of age was also found to approximate $50 \%$ of the adult level $(17,22)$. Moreover, as in the present study, the $V_{\max }$ and $K_{\mathrm{m}}$ values for 5'-phosphatase in the maturing rat brain were found to significantly exceed the corresponding 3 '-kinase determinations (22). On the other hand, our observed maturational decrease in 5 -phosphatase 
activity in rabbit TSM contrasts the reported developmental increase in the activity of the enzyme in rat brain $(17,22)$, suggesting the presence of interspecies and/or tissue-specific differences in its developmental regulation.

Our present findings regarding the regulation of 3 '-kinase activity are in agreement with recent studies using different cell types which reported that the activity of the enzyme is stimulated by physiological concentrations of $\mathrm{Ca}^{2+}$, with an optimal effect elicited at $\sim 10^{-6} \mathrm{M}$ free $\mathrm{Ca}^{2+}$ concentration (22-25). In this connection, we observed that maximal 3'-kinase activity was significantly increased in the presence of $10^{-6} \mathrm{M}$ free $\mathrm{Ca}^{2+}$ in both the immature and adult TSM preparations (Fig. 7). Moreover, the present results indicated that, relative to control conditions, the absolute magnitude of increase in the mean $V_{\max }$ values for $3^{\prime}$-kinase in the $\mathrm{Ca}^{2+}$-stimulated state was similar in the 2-wk-old and adult TSM, amounting to +85.4 and $+88.6 \mathrm{pmol} / \mathrm{min}$ per $\mathrm{mg}$ protein, respectively (Fig. 7 ). Whereas this finding suggests that the degree of $\mathrm{Ca}^{2+}$ sensitivity of $3^{\prime}$-kinase is similar in the immature and adult TSM, the observed persistence of a significant maturational difference in maximal 3'-kinase activity in the $\mathrm{Ca}^{2+}$-stimulated state (Fig. 7) suggests that the data accurately reflect age-related changes in intrinsic 3'-kinase activity. Indeed, the latter notion is further supported by the observed similarities of the $K_{\mathrm{m}}$ values for both $3^{\prime}$-kinase and 5'-phosphatase when the 2-wk-old and adult tissues are compared. In this regard, however, it should be noted that ultimate confirmation with antibodies specific for the $\operatorname{Ins}(1,4,5) \mathrm{P}_{3}$ degradative enzymes would provide conclusive evidence of true maturational changes in enzyme concentration. Moreover, to the extent that measurement of the apparent activities of these enzymes may be influenced by other factors, including covalent modification by protein phosphorylation $(27,28)$, it is possible that the observed ontogenetic changes in the activities of $3^{\prime}$-kinase and 5'-phosphatase reflect potential variation in their respective states of covalent modification.

In light of the present findings, it is of interest to consider the consequences of the observed developmental changes in the rate and the route of $\operatorname{Ins}(1,4,5) \mathrm{P}_{3}$ metabolism in the maturing airway. The dephosphorylation of $\operatorname{Ins}(1,4,5) \mathrm{P}_{3}$ via 5 '-phosphatase represents a functionally inactivating route, since there is no known physiological action of the product, $\operatorname{Ins}(1,4) \mathrm{P}_{2}$. Phosphorylation of $\operatorname{Ins}(1,4,5) \mathrm{P}_{3}$ by $3^{\prime}$-kinase, on the other hand, rapidly produces Ins $(1,3,4,5) \mathrm{P}_{4}$ which may interact synergistically with $\operatorname{Ins}(1,4,5) \mathrm{P}_{3}$ to regulate $\mathrm{Ca}^{2+}$ transients $(13$, $29)$. Since the same $5^{\prime}$-phosphatase also degrades $\operatorname{Ins}(1,3,4$, 5) $P_{4}$, the present findings suggest that, as the airway smooth muscle matures, its capacity to generate $\operatorname{Ins}(1,3,4,5) \mathrm{P}_{4}$ is enhanced while its capacity to degrade it is reduced. The net effect would be to increase the average $\operatorname{Ins}(1,3,4,5) \mathrm{P}_{4}$ concentration during agonist stimulation, whereas the concentration of Ins(1, $4,5) P_{3}$ is relatively reduced. In this regard, it should be further noted that 5 -phosphatase has a greater affinity for $\operatorname{Ins}(1,3,4$, 5) $P_{4}$ than for $\operatorname{Ins}(1,4,5) P_{3}(8,29,30)$. The latter may have physiological importance since, in the presence of increased levels of $\operatorname{Ins}(1,3,4,5) \mathrm{P}_{4}$, dephosphorylation of $\operatorname{Ins}(1,4,5) \mathrm{P}_{3}$ would be reduced.

It must be emphasized that the above considerations are largely speculative, as it would be an oversimplification to assume that the measured maturational differences in the apparent activities of the two metabolizing enzymes are directly reflected in the metabolic fate of $\operatorname{Ins}(1,4,5) \mathrm{P}_{3}$ in the intact airway.
In this context, a number of factors including the degree of substrate and/or enzyme compartmentation, modulation of enzyme activity by various regulatory processes (e.g., covalent modification), as well as the relative density of $\operatorname{Ins}(1,4,5) \mathrm{P}_{3}$ receptors at sites responsive to intracellular $\mathrm{Ca}^{2+}$ release, may all serve as additional determinants of the metabolism of Ins $(1,4,5) \mathrm{P}_{3}$ and, accordingly, its second messenger function. Moreover, apart from the production and metabolism of Ins $(1,4,5) \mathrm{P}_{3}$, the processes coupling Ins $(1,4,5) \mathrm{P}_{3}$ accumulation to airway smooth muscle contraction and force generation may also significantly vary during maturation. Thus, whereas the present study provides new evidence that maturational changes in agonist-induced airway contractility are associated with ontogenetic variation in the activities of the enzymes which metabolize Ins $(1,4,5) \mathrm{P}_{3}$, the relative contributions of the above additional regulatory factors remain to be determined.

\section{Acknowledgments}

The authors wish to thank S. Ling and J. S. Grunstein for their expert technical assistance, and P. Lorenski for preparation of the manuscript.

This study was supported by National Heart, Lung, and Blood Institute, National Institutes of Health grant HL-31467.

\section{References}

1. Hayashi, S., and N. Toda. 1980. Age-related alterations in the response of rabbit tracheal smooth muscle to agents. J. Pharmacol. Exp. Ther. 214:675-681.

2. Brink, C., P. G. Duncan, M. Midzenski, and J. S. Douglas. 1980. Response and sensitivity of female guinea-pig respiratory tissues to agonists during ontogenesis. J. Pharmacol. Exp. Ther. 215:426-433.

3. Wills, M., and J. S. Douglas. 1988. Aging and cholinergic responses in bovine trachealis muscle. Br. J. Pharmacol. 93:918-924.

4. Murphy, T. M., R. W. Mitchell, J. S. Blake, M. M. Mack, E. A. Kelly, N. M. Munoz, and A. R. Leff. 1989. Expression of airway contractile properties and acetylcholinesterase activity in swine. J. Appl. Physiol. 67:174-180.

5. Montgomery, G. L., and R. S. Tepper. 1990 . Changes in airway reactivity with age in normal infants and young children. Am. Rev. Respir. Dis. 142:13721376.

6. Duncan, P. G., C. Brink, and J. S. Douglas. 1982. $\beta$-receptors during aging in respiratory tissues. Eur. J. Pharmacol. 78:45-52.

7. Whitsett, J. A., A. Machulskis, A. Noguchi, and J. A. Burdsall. 1982. Ontogeny of $\alpha_{1}$ and $\beta_{1}$-adrenergic receptors in rat lung. Life Sci. 30:139-145.

8. Majerus, P. W., T. M. Connolly, H. Deckmyn, T. S. Ross, T. E. Bross, H. Ishii, V. S. Bansal, and D. B. Wilson. 1986. The metabolism of phosphoinositidederived messenger molecules. Science (Wash. DC). 234:1519-1526.

9. Abdel-Latif, A. A. 1986. Calcium-mobilizing receptors, polyphosphoinositides, and the generation of second messengers. Pharmacol. Rev. 38:227-272.

10. Berridge, M. J. 1987. Inositol trisphosphate and diacylglycerol: two interacting second messengers. Annu. Rev. Biochem. 56:159-193.

11. Putney, J. W., Jr. 1987. Formation and actions of calcium mobilizing messenger inositol 1,4,5-trisphosphate. Am. J. Physiol. 252:G149-G157.

12. Miller-Hance, W. C., J. R. Miller, J. N. Wells, J. T. Stull, and K. E. Kamm. 1988. Biochemical events associated with activation of smooth muscle contraction. J. Biol. Chem. 263:13979-13982.

13. Rana, R. S., and L. E. Hokin. 1990. Role of phosphoinositides in transmembrane signaling. Physiol. Rev. 70:115-164.

14. Grunstein, M. M., S. M. Rosenberg, C. M. Schramm, and N. A. Pawlowski. 1991. Mechanisms of action of endothelin-1 in maturing rabbit airway smooth muscle. Am. J. Physiol. (Lung Cell Mol. Physiol.). 260:L434-L443.

15. Huang, C., and H. E. Ives. 1989. Guanosine 5'-O-(3-thiotrisphosphate) potentiates both thrombin and platelet-derived growth factor-induced inositol phosphate release in permeabilized vascular smooth muscle cells. J. Biol. Chem. 264:4391-4397.

16. Lowry, O. H., N. J. Rosebrough, B. L. Farr, and R. J. Randall. 1951. Protein measurement with the Folin phenol reagent. J. Biol. Chem. 193:283-287.

17. Moon, K. H., S. Y. Lee, and S. G. Rhee. 1989. Developmental changes in the activities of phospholipase C, 3-kinase and 5-phosphatase in rat brain. Biochem. Biophys. Res. Commun. 164:370-374.

18. Chilvers, E. R., R. A. Challiss, P. J. Barnes, and S. R. Nahorski. 1989. 
Mass changes of inositol $(1,4,5)$ trisphosphate in trachealis muscle following agonist stimulation. Eur. J. Pharmacol. 164:587-590.

19. Kitazawa, T., S. Kobayashi, K. Horiati, A. V. Somlyo, and A. P. Somlyo 1989. Receptor-coupled, permeabilized smooth muscle. J. Biol. Chem. 264:5339-5342.

20. Kobayashi, S., T. Kitazawa, A. V. Somlyo, and A. P. Somlyo. 1989 Cytosolic heparin inhibits muscarinic and $\alpha$-adrenergic $\mathrm{Ca}^{2+}$ release in smooth muscle. J. Biol. Chem. 264:17997-18004.

21. Murray, R. K., C. F. Bennett, S. J. Fluharty, and M. I. Kotlikoff. 1989. Mechanism of phorbol ester inhibition of histamine-induced $\mathrm{IP}_{3}$ formation in cultured airway smooth muscle. Am. J. Physiol. (Lung Cell Mol. Physiol.). 257:L209-L216.

22. Heacock, A. M., E. B. Seguin, and B. W. Agranoff. 1990. Developmental and regional studies of the metabolism of inositol 1,4,5-trisphosphate in rat brain. J. Neurochem. 54:1405-1411.

23. Takazawa, K., M. Lemol, A. Delvaux, C. Lejeune, J. E. Dumont, and C. Erneux. 1990. Rat brain inositol 1,4,5-trisphosphate 3-kinase. Biochem. J. 268:213-217.

24. Biden, T. J., M. Comte, J. A. Cox, and C. B. Wolheim. 1987. Calcium-cal- modulin stimulates inositol 1,4,5-trisphosphate kinase activity from insulin secreting RINm5F cells. J. Biol. Chem. 262:9437-9440.

25. Yamaguchi, K., M. Hirata, and H. Kuriyama. 1987. Calmodulin activates inositol 1,4,5-trisphosphate 3-kinase activity in pig aortic smooth muscle. Biochem. J. 244:787-791.

26. Balduini, W., S. D. Murphy, and L. G. Costa. 1987. Developmental changes in muscarinic receptor-stimulated phosphoinositide metabolism in rat brain. J. Pharmacol. Exp. Ther. 241:421-427.

27. Connolly, T. M., W. J. Lawing, Jr., and P. W. Majerus. 1986. Protein kinase $C$ phosphorylates human platelet inositol trisphosphate 5 '-phosphomonoesterase, increasing the phosphatase activity. Cell. 46:951-958.

28. Molina, Y., L. M. Vedia, and E. G. Lapetina. 1986. Phorbol 12, 13-dibutyrate and 1-oleyl-2-acetyldiacylglycerol stimulate inositol trisphosphate dephosphorylation in human platelets. J. Biol. Chem. 261:10493-10495.

29. Shears, S. B. 1989. Metabolism of the inositol phosphates produced upon receptor activation. Biochem. J. 260:313-324.

30. Majerus, P. W., T. M. Connolly, V. S. Bansal, R. C. Inhorn, T. S. Ross, and D. L. Lips. 1988. Inositol phosphates: synthesis and degradation. J. Biol. Chem. 263:3051-3054. 